\title{
IMPACT OF CONFLICT BETWEEN REGIONAL PLANNING POLICY AND CITIES STRATEGIES UPON CITIES URBAN SITUATION CASE STUDY: MANSOURA CITY, EGYPT
}

\section{Dalia Hussain El-Dardiry}

Assistant Professor of Urban Developing, Alexandria University

\section{Eslam El-Ghonaimy}

Associate Professor of Architecture, Alexandria University

(Received June 23, 2009 Accepted October 19, 2009).

This paper discuss the problem of urban growth of metropolitan cities, which often occur steadily at the expense of land, especially if the attention of planners urban development comes in the framework of achieving people's needs and maintain the city's resources in a balanced, and that witnesses the world to economic changes and transformations with multiple end of the twentieth century and the beginnings of the new century (globalization, new world economic order, a revolution of information and communication). These global changes will have significant impact on the attitudes of urban development in Egypt, especially in determining the direction and rate of urban development.

The reasons for choosing the city of Mansoura to a case study because of its specifications are similar to the regional cities which are urban growth at the expense of the surrounding agricultural land, the growth is not simple, particularly as it is on the agricultural land classified as firstclass in terms of quality and richness of soil productivity and crop structure.

Hence the importance of studying and monitoring the growth of the city to prevent the negative effects of unregulated growth and shows that significantly through the study of urban growth of the city from 1903 until now. Therefore, research aims to:

- assess the usefulness of governmental actions to the problems of urban growth and the success of the planned destruction of the city of Mansoura in 2012 to solve the problem of urbanization and the development of residential areas degraded.

- to provide the best solutions to overcome the problems of urban growth (urban and environmental), by providing a new vision of the concept applied to the nature of the planned destruction of the city of Mansoura to impose conditions and improve the quality of housing, through an overview of the future based on communication and sustainability, and optimal utilization of available resources in the city.

- analysis and evaluation of policies and strategies proposed to solve the problems of urban growth in the development plans to provide a new vision of the scheme of the city of Mansoura year. 
- He specialized in research examining the negative consequences for the growth of the city of Mansoura to unplanned land use and therefore the residential areas, then make several assumptions have been aimed at achieving the objective of the research are as follows:

- the level in the Nile Delta: The Politics of Urban Development Region must be consistent with the absorptive capacity of cities in the region taking into account the mutual influences between these cities to each other.

- the level of Daqahliya: policies and strategies to solve the problems of land should be through a policy of comprehensive, integrated and not part of these strategies should be based on the thought of sustainable development.

- the level of the city of Mansoura: The planned destruction of the city of Mansoura in 2012 is not appropriate to resolve the problems urban city, the new thought for another comprehensive plan must be submitted.

- Method of research is descriptive method of the suit and comparative study between the target and has been implemented - the analytical method to analyze urban growth of the city - the measurements and analysis of the results of these measurements, especially for the extent of contamination incident in the city.

\section{INTRODUCTION}

Throughout the world, most actions on human settlement development tend to occur outside or ahead of plans, and sometimes even against them. This development is always being controlled by some sort of roles and laws and is usually monitored by the local authorities. In other hand, development is handled and organized by certain hierarchy; each rank of the hierarchy takes the responsibility of certain level (Region, Government, Cities) which managed policy, strategy and action process.

In order to reconcile social, economic and functional efficiency with physical and environmental constraints, the performance of Urban Planning Policy and Strategies in Cities Urban Developing need to be monitored and evaluated. Changes, required to improve the quality of life in them can be recognized and encouraged through the appropriate measures. The key factors of changing, including the nature and the impact of their interrelationship, need to be identified. To a great extent, the planning process then becomes a control exercise in which all these forces are described in several alternative situations for the purpose of meeting specific goals in time and space. Behavior of these forces cannot always be predicted, so feedback information is necessary to reevaluate initial goals and objectives.

The development studies criteria take three main axes which are Human resources; Urban and natural resources; System of government and urban management. If any rational decisions related to the dynamics of urban environment should be taken a careful evaluation and close monitoring coherently adapted to the overall is to be considered. Many researchers and research projects were attracted to examine these issues. This paper had the opportunity to study such considerations after time of the previous researches findings (about indicators of the urban environment quality and 
understanding of movement towards or away from goals or standards) that based on previous personal joining and participating by researcher in such studies of City urban problems.

\subsection{Diagnosis of the problem}

Generally, City urban developing always occurs in two main forms.

- "Planned urban developing form" that follows the urban planning theories and rules and follows the governmental laws and regulations. The resulting urban areas are characterized by the accepted standard of life and good housing conditions.

- The other urban developing form is haphazard and follows no rule or regulation. The resulted urban pattern is characterized by the deteriorated land uses especially for residential areas and housing conditions.

The Conflict of Urban Planning Policy and Strategies in Cities Urban led to the second type, which is "haphazard form" causes in particular, many urban problems, such as overcrowded residential areas, infrastructure problems and mal-distribution of city services. Also, it produces miss use of lands, which generate adverse impacts, in general, to the environment and in particular to the residential areas consequently deteriorate

- housing condition

- quality of life

- standard of living

\subsection{Significance of studying "El-Mansoura" city}

Deterioration of city urban quality and losing of the best agricultural land surrounding "El-Mansoura" City occur, which forms an urban encroachment, economic and environmental disaster, loosing its enormous resources and opportunities and its impacts on both the urban and agricultural areas. Many workshops by local authorities, Non governmental societies and Academic faculties and institutes and others were involved in studying the impacts of this conflict phenomenon.

\subsection{Motivation of selecting "El-Mansoura" city" as case study:}

Geographically and according to its location, the Egyptian cities fall into two main types: coastal cities such as Alexandria; and internal cities such as who are located to the side of the River Nile; "El-Mansoura" City is one of them,and the best productive agricultural land in Egypt surrounds it. "El-Mansoura" City urban expansion is occurring upon this high-quality land and consequently such land is being reshaped (Fig. 1). Due to the resulted economic disaster of the conflict between Delta Region developing Policy, Dakahlia Strategies and Mansoura City Master plan targets and actions, Mansoura City was selected as case study.

\subsection{Research Idea}

Idea of research is to revise the integration between urban planning and urban development strategies in helping enlighten development policy. In spite of the 
important of this issue, it is still conflict between planning departments leading to lose the economic base of the city. So, idea of rising question of "How can urban planning and urban development strategies be integrated into and help inform national and international development policy?" is the basic research idea.

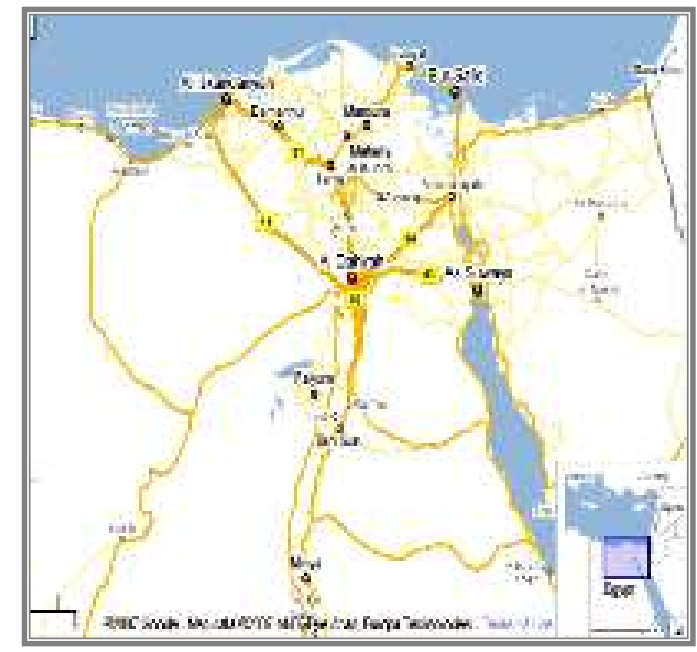

Fig. 1: Mansoura City general location to Egypt

\subsection{Aim of the research}

The study's concern is focused towards the impacts resulted from the conflict between Urban Planning Policy and Strategies in Cities Urban Development. Then propose the possibility of activating the "integration vision" strategy helping enlighten national and international development policy.

\subsection{The research methodology}

Type, facility, opportunity and suitability are the major effective elements in choosing the suitable methodology in studying city urban problems as follows:

- Descriptive methodology to detail the urban deveopment phenomena and the urban encroachment problems in Delta region and Dakahlia governorate.

- "The survey and the comparison" method for certain data is used to overcome the shortage of some types of data and ensure the accuracy.

- The review phase of the collected data is important to assess the current phase which is followed by the developing of the plan of the work

\subsection{Framework and Plan of the research}

Achieving the aim of the study, the analytical and evaluation methodology is chosen basically on the following sequential steps:

- Analysis of regional urban development policy and strategy.

- Presenting the Environmental Impact Assessment of "El-Mansoura" City urban development. 
- Filling the strengths, weaknesses, opportunities and threats (S.W.O.T.) table.

- Presenting a conceptual vision for the master plan.

\section{DELTA REGION, EGYPT}

\subsection{Introduction, Reviewing the case of Egypt}

Egypt is located on the northeast corner of the African continent and encompasses a million square kilometers. More than $90 \%$ of the population lives on the delta of the Nile and its banks. Egypt is not found in the rich districts of Cairo and Alexandria, but in its 1,200 informal settlements, and four thousands villages and their satellites.

Population in Egypt is growing to almost $2 \%$ per annum, which means decreasing the per capita share of fresh water. Arable land is also limited. An estimated 95\% of the population of Egypt is concentrated in about $4 \%$ of the gross area. Main sources of national income are exports of agricultural products, raw materials, petroleum and natural gas, tourism, Suez Canal revenues and remittances of workers abroad.

According to UN population projections, the population of Egypt is expected to exceed one hundred million by the year 2030-35. The projections suggest that urban population will start to be the majority around $2020 .^{(1)}$ (Fig2)

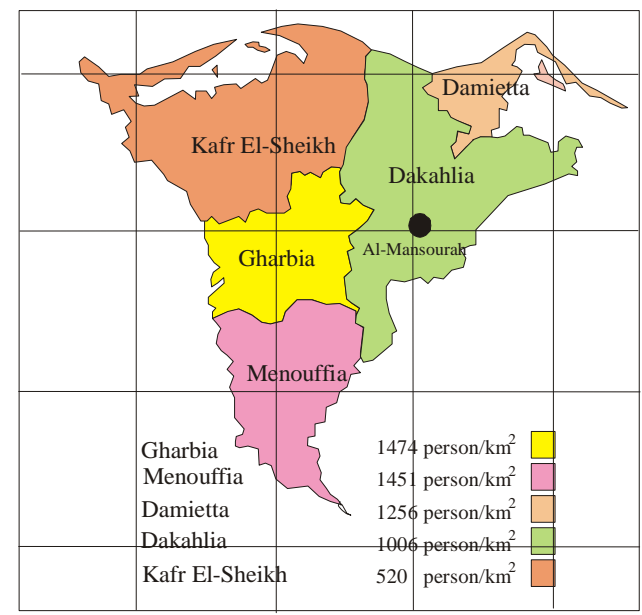

Fig. 2: Egypt, Delta region.

\subsection{Population in Urban areas:}

Average population densities exceed 1000 peoples $/ \mathrm{km}^{2}$ for the Nile valley and Delta which represent $3.6 \%$ of national territory. However since almost all-agricultural

(1) Ahmed O. El-Kholei, Transformations in Popular Attitude, Customs and Beliefs: A Framework for the Development of Poor Rural Settlements in Egypt, Prepared for Conference on Rural-Urban Linkages Organized by The General Organization for Physical Planning Cairo, Egypt, 13-16 December 2005 
production is concentrated in the Nile valley and Delta, rural population densities are very high. Egypt, administratively, is divided into 28 governorates; four of them are completely urban governorates (Cairo, Alexandria, Port Said, and Suez). Meanwhile each one of the remaining governorates consists of both urban and rural areas. ${ }^{(1)}$

Egypt as one of the third world countries has been experiencing an enormous population increase; particularly in urban areas, a continuous flow of rural-urban migration; such conditions led to rapid expansion of Egyptian urban areas, which in most cases was unplanned and spontaneous

Figures 3 and 4 show that Egypt has been predominantly rural since the 1950s. In 1950, almost $70 \%$ of the population lived in rural areas. Those living in rural areas in 2030 are expected to represent only $46 \%$ of the total population of Egypt. Urban growth results from sustaining high rates of natural population growth and successive influx of rural-urban migration.

Urban population is not evenly distributed among the 219 cities, in which they live. The analysis of the detailed results of the latest census, 1996, indicates that the Egyptian urban system is suffering from the primacy problem that negatively affects the distribution of resources and investments. Meanwhile, the population of 77 cities accounts for $4 \%$ of the urban population and about $2 \%$ of the total population of Egypt.

Often urban primacy and regional disparities associate with social and economic problems, such as unemployment, poverty, excessive influx of rural-urban migrants and denying marginalized sub-populations" access to power and wealth.

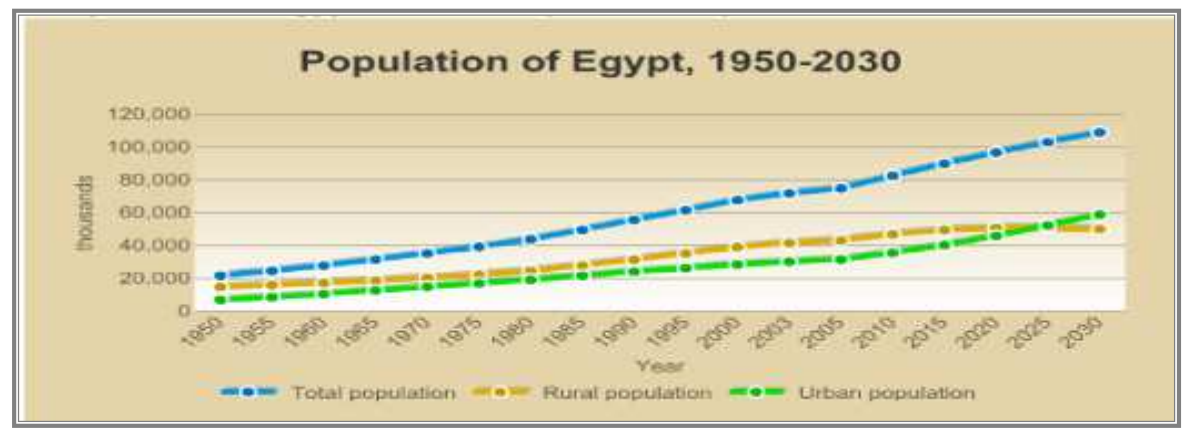

Fig. 3: Population of Egypt 1950-2030 (thousands)

Source: Data complied from World Urbanization Prospects, 2003, http://esa.un.org/unup/index.asp?panel=1

\subsection{Delta region urban problems:}

Delta region is one of seven regional divisions. Delta region is consists of five governorates, which are Kafr El-Sheikh, Gharbia, Menouffia, DAKAHLIA and Damietta governorates, Delta region governorates are characterized by high agricultural land value and the large economic attractive urban center. Urban encroachment is the major problem that affects negatively the economic

(1) El-Dardiry, D. H., Environmental housing conditions in new urban settlements in Egypt, Ms.c. thesis submitted to institute of graduate studies and research, University of Alexandria, 1997, P51. 
development process. which are considered to lead to huge economic disaster. Governments tried to stop or decrease the phenomena by presenting a master urban plan for such urban centers. Regulation and law were directed to face this phenomenon thus urban planning was directed to follow the urban law number (3) for the year of 1982 .

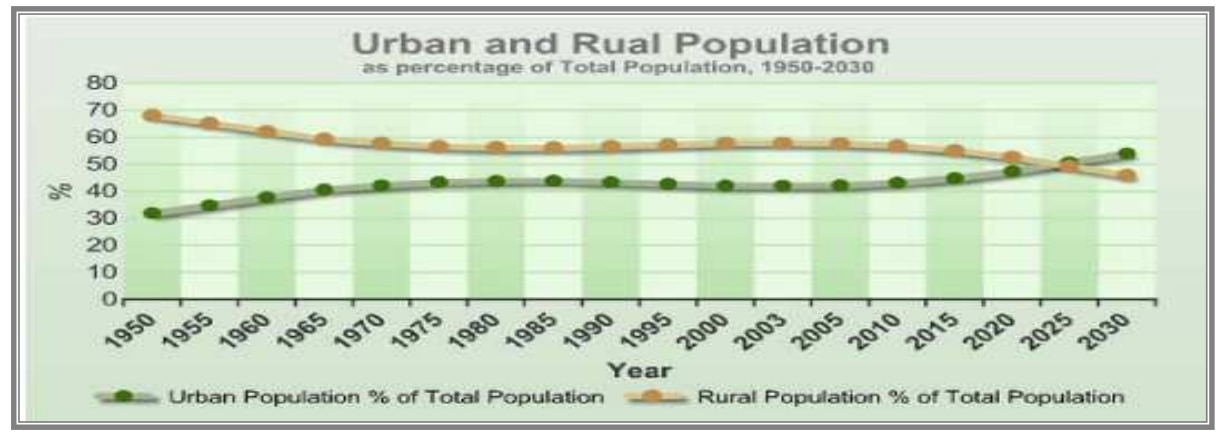

Fig. 4: Urban and Rural Populations as Percentage of Total Population, 1950-2030 (1)

Ref: Ahmed O. El-Kholei, Transformations in Popular ... Cairo, Egypt, 13-16 December 2005

\subsection{Main urban characteristics of the Delta region: (2)}

The main urban characteristics of the Delta region include the followings:

\subsubsection{Spatial characteristics:}

Urbanization characteristics in Delta region are different from the south than the north due to the different physical characteristic. Sanitation, land erosion and high sea level and others are considered to be major regional problems. Shoreline changes as a result of the physical factors. Al-Buroles and Al-Manzala as two big lakes affect permanently the land characteristics.

\subsubsection{Economic characteristics:}

Integration between regional governorates is the main character of the diversity of the economic activities and the dominant agricultural activity. Multi interaction activities within the regional borders act with the economic elements as a one integrated unit (Agricultural engineering and traditional industries, and Handcraft) which encourages the investment in craft industries. Tourism development facilities have not strong impact.

\subsection{Urbanization balance \& Strategic regional development in Delta region:}

(1) Internet http://ideas.repec.org/p/dia/wpaper/dt200408.html

(2) Abdel Fattah Nassef et all, Egypt human development report, UNDPE\&INP, Cairo,1996, P.P 135-136 
Unbalance characterizes the urbanization process in the Delta region. The local migration from the rural to urban areas is considered as a major factor. ${ }^{(1)}$ The unbalance done due to the increasing of the population numbers in the three existing cities, which are "El-Mansoura", Tanta and Al-Mahala Al-Kobra cities, which reach the urbanization balance threshold. The main points, which the existing strategy of the Delta region focused on, are as follows:

- A short term policy, which determine the urbanization zone for the urban communities and the factors controlling the urban expansion on the rural land.

- A long term strategy, which includes the management of the urban expansion in the Delta region in general and in particular in the civic centers in the form of integration policy for the Delta Region and its surrounding regions. ${ }^{(2)}$

Consequently, the conflict of Delta region cities developing begins to start from the strategic economic development plan, which was mainly directed to absorb 10 million people by 2020in the region. The factors affecting the development are:

- Population growth and economic development.

- Unplanned urbanization and acute shortage of houses supply.

- Absence of the location dimension in the last national planning. ${ }^{(2)}$

\section{DAKAHLIA GOVERNORATE}

Dakahlia governorate is located in the north of Egypt. It is between 30o 20/ and 310 20/-north latitude, and between $30 \mathrm{o} 5 /$ and 310 5/-east longitude, ${ }^{(3)}$ Fig5. The governorate's area is about $3470.90 \mathrm{~km}^{2}$. The ratio of the whole governorate area in comparison to that of the republic is $0.35 \%$. ${ }^{(4)}$ The river Nile passes through the governorate or the especially in "El-Mansoura", which is the capital of the governorate, studying the outlines of the governorate urban characteristics is important to clarify the urban problems in general and the land problems in particular.

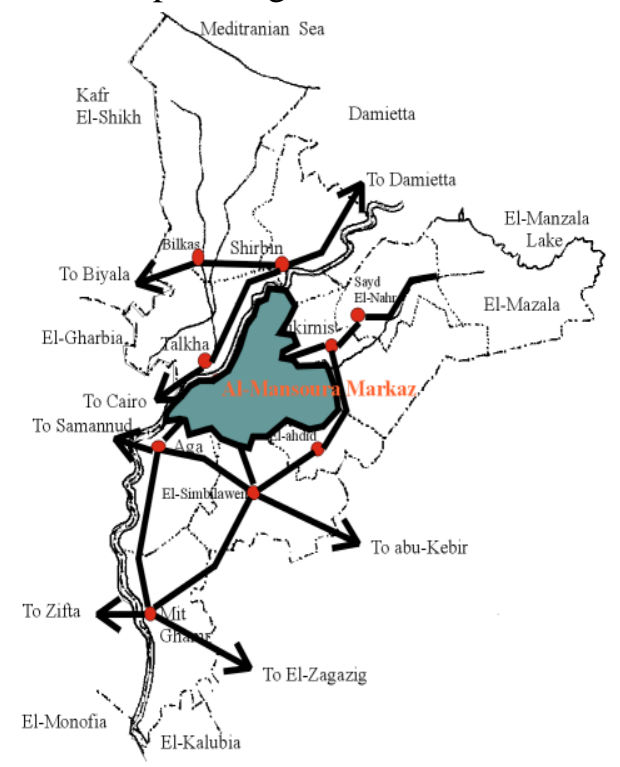

Fig5: Dakahlia governorate division 1996.

Source: Regional planning for Dakahlia governorate by 2017.

\subsection{Population From the detailed study it is found that:}

- The Population density is very high in the

(1)General Master Plan of El-Mansoura and Talkha Cities, for the year 2012, P.P. 5-20.

(2)Housing international conference, Policies \& housing systems for low income communities, Governments role in self-help housing in urban developing areas: the site and services approach., Ministry of development, New communities housing and public utilities., Cairo, 1992, P. 55

(3)Topography map in atlas of Egypt. Scale 1: 100.000.

(4) Dakahlia governorate, supporting and decision-making center, 1998, P.2 
-middle and the south of the governorate, while it decreases gradually towards the north.

- "El-Mansoura" City and Meet-Ghamr represent the highest population densities among the fourteen "Marakez" of the governorate with a population density over 2000 person $/ \mathrm{km} 2$. $^{(1)}$

The continuo increase of the population density means wide urban extensions over the arable land, which causes severe economic, social and environmental problems.

As mention before, the Delta is over populated. Consequently, Dakahlia governorate urban population is growing with higher rates than rural population (due to rural/urban immigration), Fig6. This may indicate that urban centers (especially "El-Mansoura" City) are attracting not only rural population of the governorate, but also immigration from the surrounding area of the Delta region and Egypt, ${ }^{(2)}$

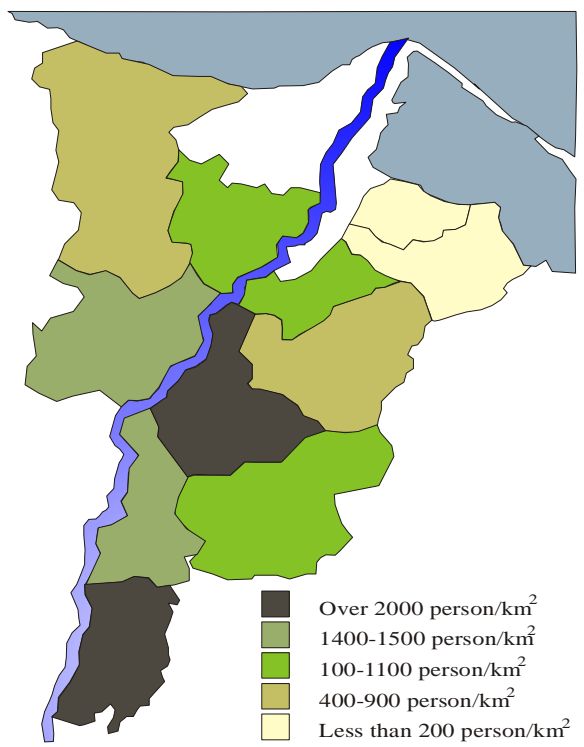

Fig. 6: Population governorate's counties. Source: Fisal and Mesheraf,1995,P.11 Table 1 .

Table 1, Urban and rural population growth rates of Dakahlia governorate, Delta region and Egypt, 1947-1986

\begin{tabular}{|l|c|c|c|c|}
\hline \hline Administrative & \multicolumn{5}{|c|}{ Population growth rate \% } \\
\hline Unit & $\mathbf{1 9 4 7 - 1 9 6 0}$ & $\mathbf{1 9 6 0 - 1 9 6 6}$ & $\mathbf{1 9 6 6 - 1 9 7 6}$ & $\mathbf{1 9 7 6 - 1 9 8 6}$ \\
\hline Dakahlia G. & & & & \\
\hline Urban & 3.00 & 4.57 & 3.22 & 3.35 \\
\hline Rural & 2.39 & 1.68 & 1.31 & 2.14 \\
\hline Total & 3.04 & 2.23 & 1.73 & 2.44 \\
\hline Delta region & & & & \\
\hline Urban & 2.78 & 4.33 & 2.76 & 2.84 \\
\hline Rural & 2.08 & 1.55 & 1.45 & 2.35 \\
\hline Total & 2.50 & 2.14 & 1.76 & 2.47 \\
\hline Egypt & & & & \\
\hline Urban & 3.26 & 3.94 & 2.78 & 2.84 \\
\hline Rural & 1.29 & 1.66 & 1.26 & 2.76 \\
\hline Total & 2.39 & 2.53 & 1.89 & 2.80 \\
\hline \hline
\end{tabular}

Source: Mesheraf and Fesal, 1995, P. 10.

\subsection{Dakahlia governorate land problems:}

Urban land is gained by losing agricultural land in Dakahlia governorate. It could be

(1) G.O.P.P, Comprehensive development strategy for Delta region, working Paper No.(2), Cairo, 1992.

(2) General authority of information, annual report, 1998, no-number. 
seen that there are main problems as follows:

\subsubsection{Natural losses:}

Due to climatic and environmental changes which are expected world wide during the next century, an over flow of the Mediterranean Sea level over the Delta lands together with the impact of decreasing the clay depositing in the river pass because of the High Dam in Aswan. There are no final, accurate and sharp results about the subsidence of the northern coast of Delta land under the sea level rise serious more land will be loosed.

\subsubsection{Urban expansion:}

110 informal areas inhabited by 630108 people have been identified in the different urban centers of the governorate. These informal areas represent the urban expansion of these urban centers over the surrounding arable land. Urban population living in informal housing areas represents about $53 \%$ of the total urban population of the governorate $(1,186,0130$ people). Land losses due to informal housing could be estimated to reach 5478-4847 feddans in the governorate. Since 1973, the annual losses of good arable land could be estimated to be 285- 322 feddans/year in Dakahlia governorate, which represent about $8-10 \%$ of the total losses on the national level of Egypt. By the year of $2020,30 \%$ of the total population $(6,663,000$ person) will be living in the urban areas. Assuming that urban areas will not increase (which is not feasible), population density of urban centers will rise to reach about 200-220 person/feddans in Dakahlia governorate.

Areas expected to be lost till the year 2020 due to urban extensions only are about 6692 feddans in Dakahlia governorate. This represents a severe threat to the main economic resources of the governorate, especially the new reclaimed lands, which are of a very low productivity compared with the old agricultural lands. ${ }^{(1)}$

\subsubsection{Land pollution:}

Sources of land pollution could be divided into two main sources as follows:

- Regional sources: These are sources located outside the governorate borders. Regional sources of pollution are miscellaneous and various and consequently that led to negative impacts on the lands.

- Local sources: These sources could be identified as urban, industrial and agricultural sources of pollution. Furthermore, the impacts of air and water pollution should be considered.

\subsection{Governmental action towards solving land problems in Dakahlia Governorate:}

The governmental actions towards solving land problems in Dakahlia Governorate varying from the Delta level to cities level. The Egyptian environmental law number 4, 1994 and the Military law for housing and urban design no 1 for 1998 were considered the important laws to control the land problems. Local authority urban legislation and other internal urban control applied in the form of local governmental orders and in the

(1) Dakahlia governorate, Agriculture sector, unpublished yearly report, the secretary office, 1998. 
form of city general master plans.

\subsubsection{Regional actions:}

It was noticed that the regional and the governmental level of planning did not exist in the delta region till the beginning of 1992 when an urban development plan for the northern coast of the governorate started and was finished in 1995 . $^{(1)}$

Generally, regional actions towards solving Dakahlia governorate land problems were presented in DELTA REGION GENERAL MASTER PLAN, and the LOCAL GOVERNMENTAL LEGISLATION.

\subsubsection{Governmental level actions:}

The governmental actions towards solving Dakahlia governorate land problems and environmental pollutions were presented in a GENERAL REPORT FOR DAKAHLIA GOVERNORATE PLANNING in 1992 and its development report in 1998.

\subsubsection{City level actions:}

Master plans were designed to manage some of the governorate cities urban expansion and to solve several environmental land problems, especially for the large urban cities such as "ElMansoura" City. The deterioration of the urban quality and the environment to both urban and rural settlements in "ElMansoura" City forced the government to present the general cities, fig7 (2) The Ministry of Housing and Infrastructure presented a general master plan of "El-

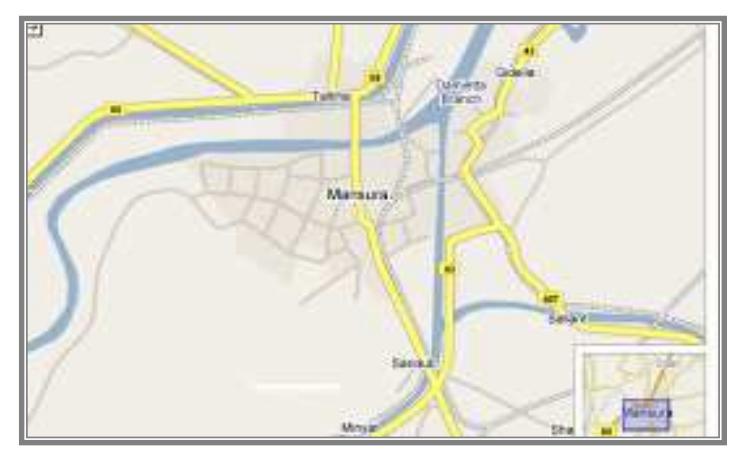

Fig7, Mansoura City general map Mansoura" City for the year 2012.

But, these levels of those master plans were directed to solve the city problems themselves without_putting into consideration the surrounding environment and the interaction or integration between the cities of the region. Many contradictions occur with DETERIORATION in the urban conditions within surrounding environment.

(1) ctually, different Departments existed at different levels with no cooperation or action plan

(2)W. A. Abd-El-All, "El-Mansoura City field studies", M. Sc. thesis, submitted Cairo University, Faculty of Arts, 1971. 


\section{VISION OF CONFLICT \& PROBLEMS OF POLICY AND STRATEGIES FOR MANSOURA CITY}

The governmental actions toward solving the "El-Mansoura" City problems were varying between the general master plan till and the governmental on the following levels:

i. Regional level, Through the regional plan of the Delta region in 1992.

ii. Governmental level,

- Through GENERAL REPORT FOR DAKAHLIA GOVERNORATE PLANNING, 1992.

- URBAN DEVELOPMENT PLAN FOR NORTHERN COASTS OF THE GOVERNORATE, 1995 in addition to the local governmental legislation.

- THE DEVELOPMENT REPORT in 1998.

iii. Local level Through the GENERAL MASTER PLAN FOR THE DELTA CITIES such as "El-Mansoura" City in 1994, Fig10.

Figure 8 illustrates the process that was designed by the researcher in studying conflict \& Problems of policy and strategies for Mansoura City general master plan, 2012. It presents Levels of conflict and the contradictions in implementing these strategies and the miss organizing between the different departments and the continuous changes in the local and international economical systems.

$\boldsymbol{B} u t$, The failing of these acts in solving "El-Mansoura" City problems occurred due to the conflict and the miss-coordination between the Ministry of Housing, Infrastructure and the New Urban Settlements departments. It should be noted that after "El-Mansoura" City master plan 2000 had failed to achieve its goals, the governorate presented another general master plan for "El-Mansoura" and "Talkha" Cities for the year 2012.

\subsection{Regional level: the Delta region planning policy:}

The policy, which is applied in the Delta region, aimed at developing the region by upgrading the main cities and identified the cities region as magnets, but each city separately. Due to this policy, these cities suffered from the accelerated uncontrollable urban expansion and the concentrating of most of the urbanization efforts on the main cities such as "El-Mansoura" cities, while only limited efforts are directed towards the remaining areas (fig9).

\subsection{Governmental level: Dakahlia urban planning development strategy:}

The strategy of Dakahlia Governorate urban planning development is to cover the entire urban pattern and the surrounding rural areas. ${ }^{(1)}$ The strategy aimed at preceding the regional policy in the governorate in the form of several action plans. These strategic action plans were directed to manage certain problems such as the reclaiming process for the desert lands and the developing of its rural communities. ${ }^{(2)}$ Another two actions were taken, one was directed to develop the northern coast and the second was directed to manage the development process near the international road.

( 1) Master Plan of El-Mansoura and Talkha Cities, 1994 P. P. 5-10.

$\left({ }^{2} 2\right)$ Two areas, existing in the northern part of Dakahlia governorate.

( 3 ) Dakahlia governorate periodical magazine, 1996, P. 37 


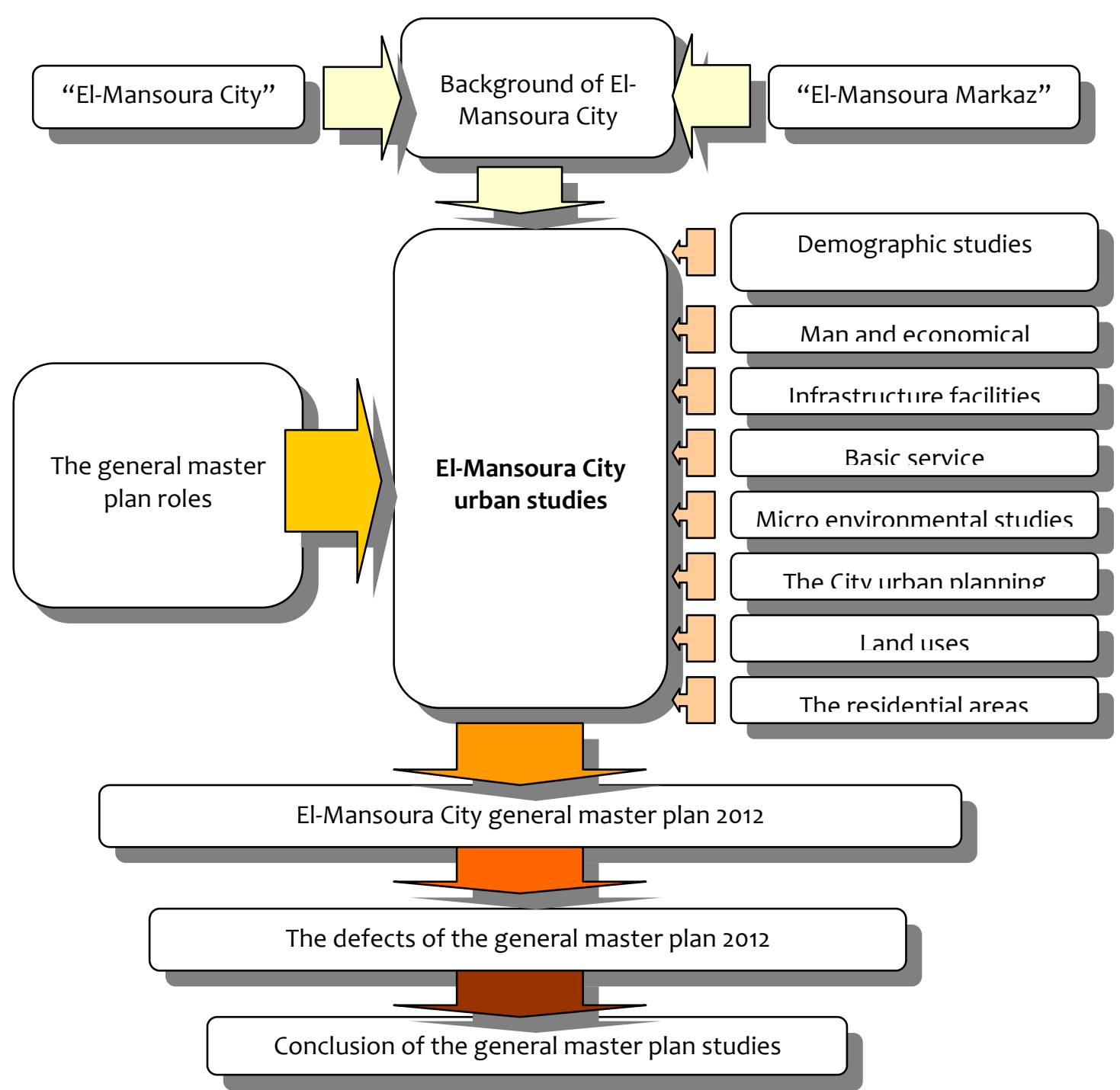

Fig. 8: illustrates the researcher process in studying "El-Mansoura" City.

\subsection{Local level: the general master plan of "El-Mansoura" City studies, 2012:}

"El-Mansoura" City is the capital of Dakahlia governorate and is located in "ElMansoura" Markaz. According to the urban planning law No. 3, 1983, item 9, the master plan was defined as "The second step of the structural planning".

In September 1994, the governorate presented "El-Mansoura" and "Talkha" (twins' cities) Cities general master plan 2012, which was approved by the local authorities and started to be implemented in the same year. 


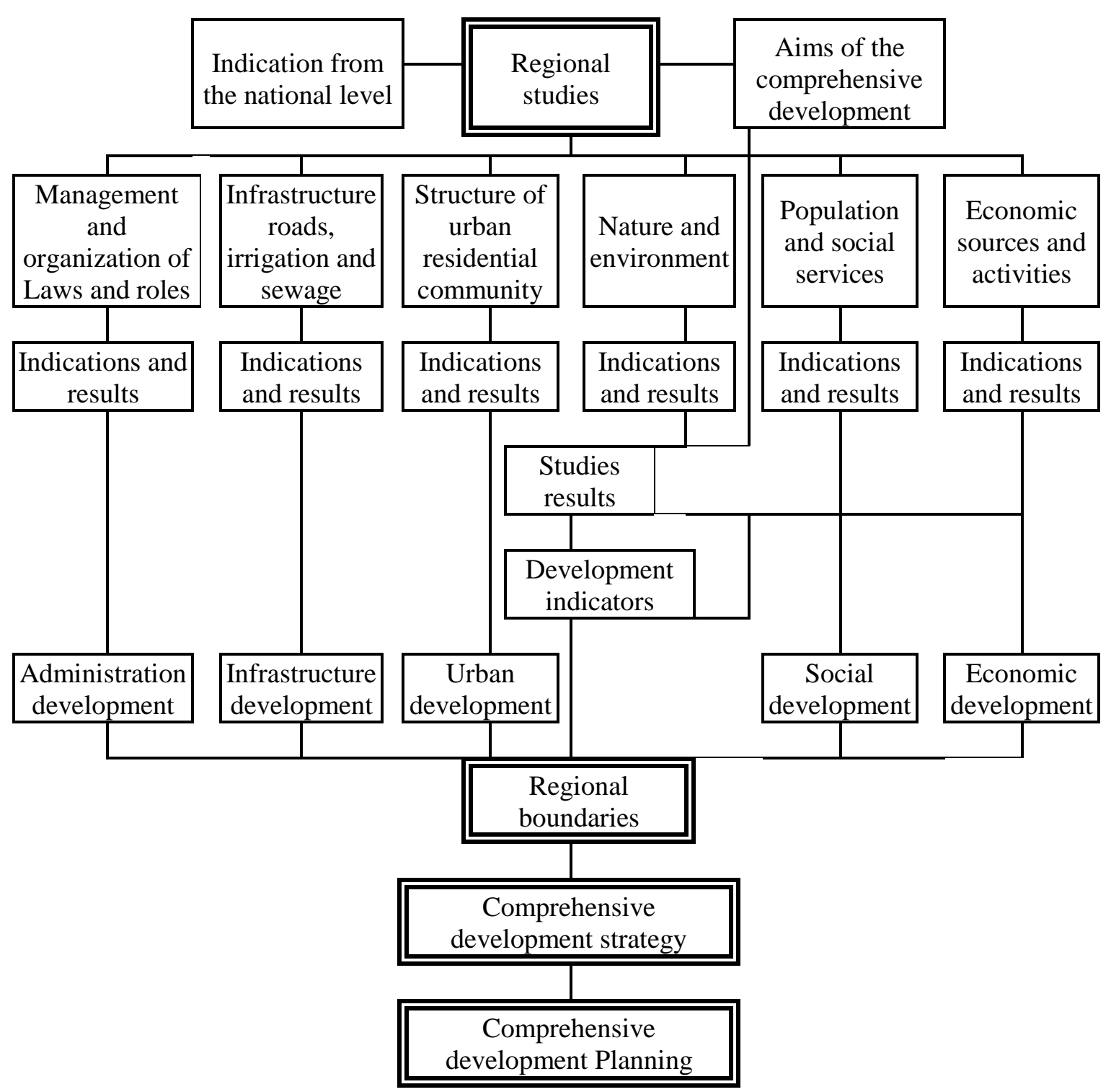

Fig. 9: Strategy of the comprehensive development of the Delta region

Source: El-Mansoura City general master plan 2012, 1994 P. 11

Conclusion from analysis the master plan, of implementation, El-Mansoura City urban activities had increased tremendously. In general, this increase was due to the goals of the master plan, which aimed at encouraging the role of El-Mansoura City as an urban center, acting as a strong magnet in the whole region of the Delta.

The state of the city was monitored hereafter, especially after the implementation of the master plan 2012, to focus on it's influence on the different urban changes.

This stage designed to review the results of applying the city master plan which was divided into two sections in which each item that it contains will be monitored separately: 
- Data base, presenting the basic urban studies such as, the demographic, man activities, infrastructure, basic services and environmental studies.

- The existing urban studies, which will be through over viewing the urban planning, land use and residential areas

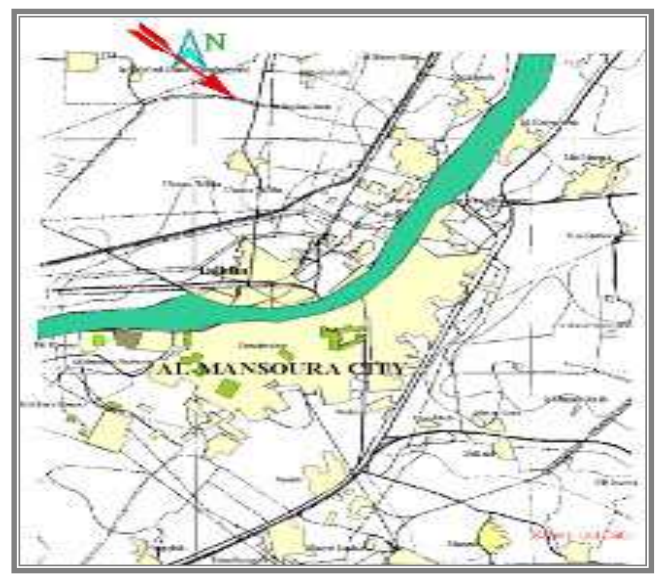

Fig. 10: El-Mansoura City in 1996.

Source: Geographical map, year of 1998

\section{EL-MANSOURA" CITY}

It is located to the northern east of the Delta region and to the eastside of the river Nile (Damietta branch). It is surrounded by very valuables cultivated agricultural land.(1) The aim of constructing "El-Mansoura" City was to protect Egypt from the foreign enemy attacks i.e., "Defense City" in 1219. Fig 10

"El-Mansoura" City urban expansion is a complete example of urban encroachment, especially with its role in the "Regional Urban Planning Concept" as "A magnet City in Delta region". ${ }^{(2)}$ So, this role lead to improper urban solutions that did not limit the disaster resulting from loss of a large amount of these productive agricultural lands surrounding El-Mansoura City, ${ }^{(3)}$.

Since the year 1527, "El-Mansoura" City has been the capital of Dakahlia governorate. It is $48 \mathrm{~km}$ away from the Mediterranean Sea. Its altitude is $6 \mathrm{~m}$ above the Mediterranean Sea level with a little slope to the seashore. The River Nile width in the site of "El-Mansoura" and "Talkha" Cities ranges between 200 to 375 meters so bridges were constructed to connect such twin cities. ${ }^{4}$ Demographically, residents of "El-Mansoura" City and "Talkha" work in both cities.

The goals of the master plan 2012 were as follows: Table 2.

(1) W. H. Habeeb. part one, 1991, P.354.

(2) Fessal \& Meshraf., P.2.

(3) W.A.Abd-El-All, 1971, P.8:13. 


\subsection{General master plan 2012 of "El-Mansoura" City roles:}

"El-Mansoura" City general master plan 2012, aimed at drawing the outlines of the urban development; the protection of the aesthetic functions to provide a healthy environment, for the welfare of the residences with providing sufficient uses in different places and high efficiency grid roads, proper traffic and infrastructure, $\mathrm{M}$. A. Hasouna, P.1.

\subsection{The general master plan of "El-Mansoura" City 2012, studies:}

"El-Mansoura" City general master plan 2012, ensured the regional role of "ElMansoura" City for serving the surrounding urban centers in the Delta in general and Dakahlia in particular. The general master plan has studied the following subjects:

- Demographic studies (Population density and increase)

- Man activities and economical studies: (Agricultural \& zoological production - Tourism - Industrial \& Commercial)

- Infrastructure facilities studies (Potable water- Electricity \& energy - Draining $\&$ sewage - Solid waste disposals - Traffic facilities - Communications grid).

- Basic services studies (Education - Health \& medical - Youth \& sport Community centers - Cultural \& religion)

- Environmental and Urban Planning studies (urban pattern - land use), fig 13-14-15

- The Residential studies (The housing situation - The buildings heights \& conditions).

- The rates of the urban expansion. Fig. 13 and Table 3.

Table 2: The general master plan 2012 goals

\begin{tabular}{|l|l|}
\hline \hline Item & Goals \\
\hline a) Economical goals: & $\begin{array}{l}\text { - Commercial: Supplying well-distributed and sufficient } \\
\text { commercial areas to attract the people and enhancing the } \\
\text { commercial activities. }\end{array}$ \\
\hline & $\begin{array}{l}\text { - Industrial: Studying and analyzing industrial activities to find } \\
\text { out the proper conditions for the zones; removing the industrial } \\
\text { areas, which caused hazards to the residences and managing its } \\
\text { pollution sources }\end{array}$ \\
\hline & - Touristical: Preservation of historical buildings. \\
& - Laborers: to arrange the laborers into the economical activities. \\
\hline b) Services goals: & $\begin{array}{l}\text { - Improving and arranging services in the city in a proper planning } \\
\text { role. }\end{array}$ \\
\hline c) Transportation goals: & $\begin{array}{l}\text { Introducing a suitable traffic network to connect the different } \\
\text { areas of the city and it‘s surrounding areas. }\end{array}$ \\
\hline d) Urban planning & $\begin{array}{l}\text { - Preparing action plans to provide the city with the main elements } \\
\text { that are necessary for the special areas such as the university } \\
\text { area. }\end{array}$ \\
\hline e) land uses goals: & $\begin{array}{l}\text { - Obtaining the best economic and social benefits for the land } \\
\text { uses. }\end{array}$ \\
\hline $\begin{array}{l}\text { - Fixing the proper land uses. } \\
\text { - Constructing new parks and recreation areas. }\end{array}$
\end{tabular}


- Determining the existing land uses to be invested in the future.

- Managing the miss-used land, which causes the health hazards.

f) Residential goals:

- Providing comfortable housing states.

- Protecting the houses in proper conditions

- Arranging, and upgrading the residential areas.

- Removing the health hazard from the residential areas.

Table 3, Urban areas between 1903 and 1996 for El-Mansoura City.

\begin{tabular}{|l|c|c|c|c|c|}
\hline Year Data & $\mathbf{1 9 0 3}$ & $\mathbf{1 9 4 7}$ & $\mathbf{1 9 7 5}$ & $\mathbf{1 9 8 8}$ & $\mathbf{1 9 6 6}$ \\
\hline Urban areas. & $2.131 \mathrm{Km} 2$ & $4.042 \mathrm{Km} 2$ & $10.199 \mathrm{Km} 2$ & $14.459 \mathrm{Km} 2$ & $17.172 \mathrm{Km} 2$ \\
\hline $\begin{array}{l}\text { Net areas of the urban } \\
\text { expansion. }\end{array}$ & - & $1.911 \mathrm{Km} 2$ & $6.157 \mathrm{Km} 2$ & $4.260 \mathrm{Km} 2$ & $2.713 \mathrm{Km} 2$ \\
\hline \begin{tabular}{l} 
Urban expansion rate. \\
\hline
\end{tabular} & - & $0.043 \%$ & $0.220 \%$ & $0.328 \%$ & $0.340 \%$ \\
\hline
\end{tabular}

The data analyzed, based on information of "El-Mansoura" City general master plan 2012, P.P. 1-17, P.P. 98-91 \& P. P. 90-107.

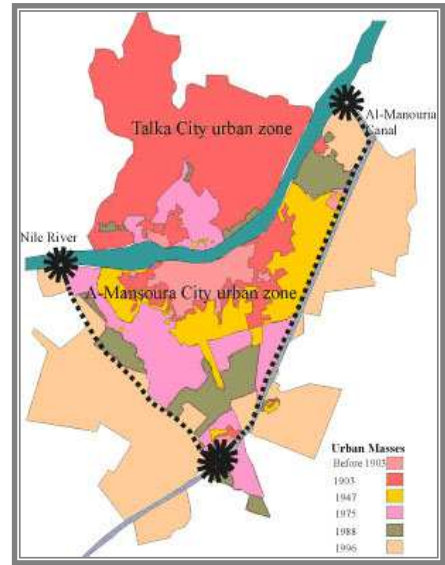

Fig11 El-Mansoura City urban expansion stages(1903till1996)

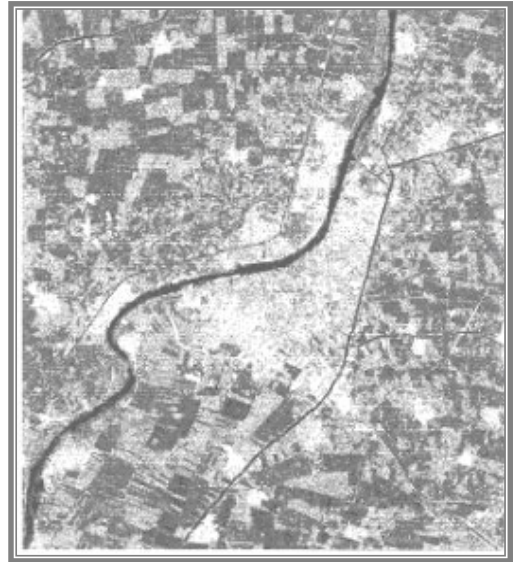

Fig12 Mansoura City 1998 Spot satellite

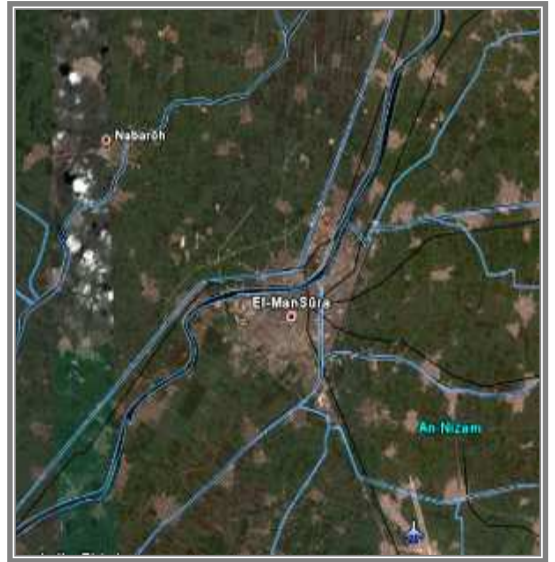

Fig13 Mansoura City Image 2008 Google - satellite image

Source: Nafea, 1998, P. 15.

\subsection{Identifying City development activities}

Due to the rapid development of the technological and the international economical changes, the urban development activities increase with a bigger rate than that of the past (review E.I.A. studies and analysis). (see fig 14).

\section{i. Urban studies:}

The main problem of the urban development is how to reach a balanced state between 
the needs and the available capabilities. ${ }^{(1)}$ The overcrowded urban pattern and the unplanned mixed land use are the major urban problems, which should be solved. The factors affecting the urban expansion in El-Mansoura City are concluded as follows:

a) The role of El-Mansoura City in Dakahlia governorate and the Delta region.

b) The developing process of Mansoura University itself and its medical institutions.

c) The Industrial development.

d) The limited area of land which could be used for future urban expansion.

\section{ii. Urban expansion studies:}

The urban expansion areas are characterized by the unplanned and haphazardly distribution of land uses, in terms of quantity and quality. Also, the skyline of the buildings in the area varies tremendously; where some buildings reach 15 storey's high other has only one floor. The streets are deteriorated, and the houses in these areas are small and below standard, also they have high population density and uncomfortable designs. The city is expected to expand with the same existing rate. High population densities, narrow unpaved streets, low income level and high rate of illiteracy are the main characteristics of these informal areas. (photos 1)
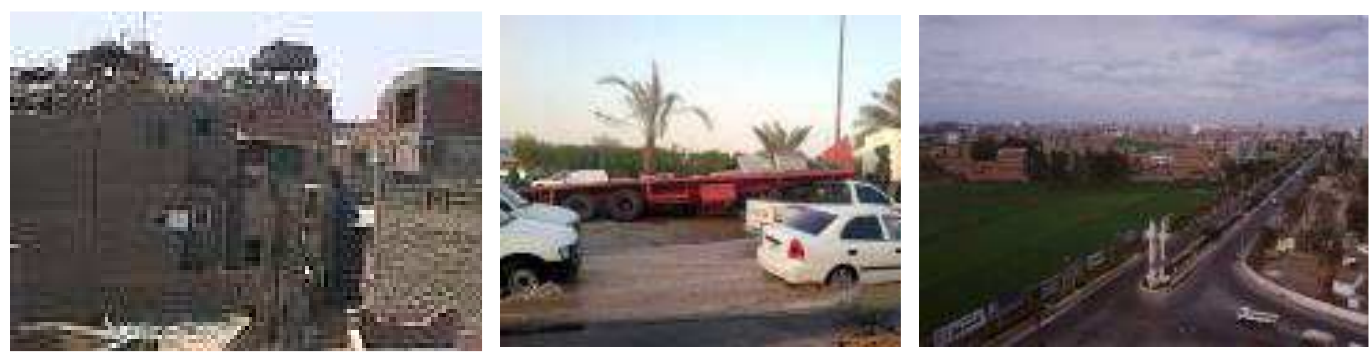

Photo1: Urban expansion problems between rural and urban life

\section{iii. Residential areas:}

The rapid urbanization and high rate of population growth together with the scarcity of land sufficient for urban expansion, and the lack of financial resources are the main reasons for the deterioration of the environment of both rural and urban settlements. Informal urban extensions spread chaotically over cultivated land. Due to the absence of proper housing conditions in the city residential areas many environmental problems are resulted. Some indicators of the deterioration of urban environment are found too.

(1) E., E., Badran, Overcrowding problems in Egypt., M.Sc., Architectural Department, Faculty of Engineering, Alexandria University, 1985, P.2 

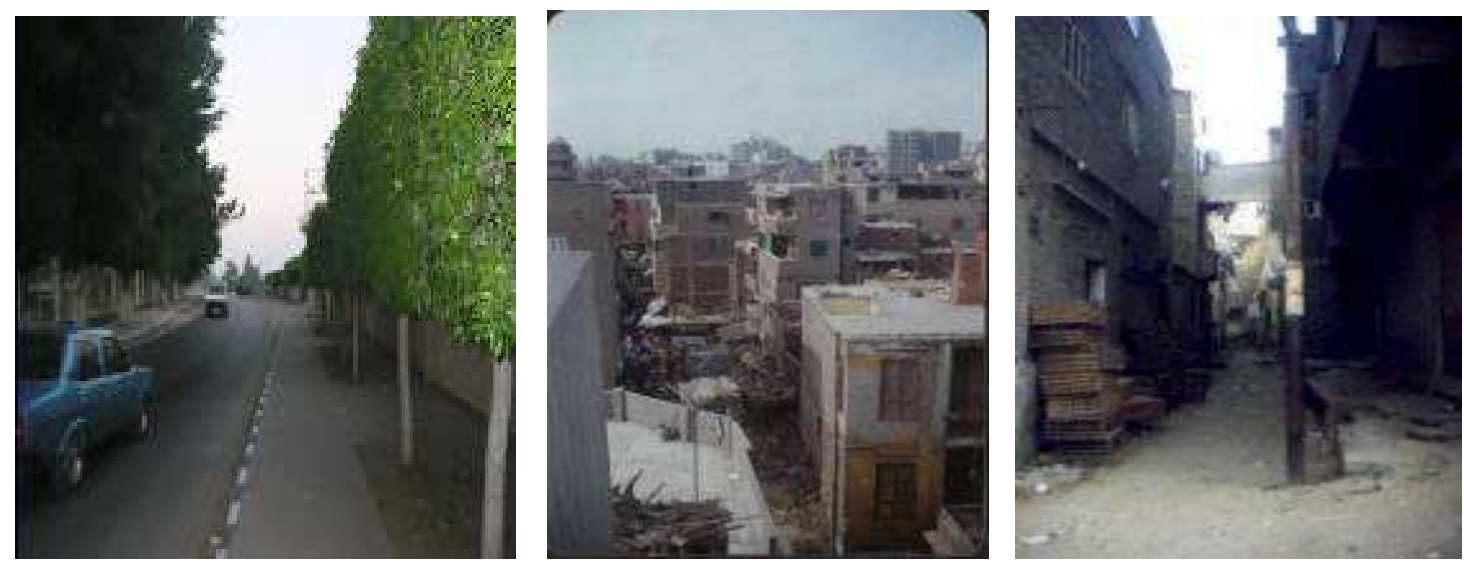

Photo2: deteriorated Residential areas inside Mansoura City

This residential land uses in the urban expansion, which occurs in the form of urban encroachment upon the agricultural land, is suffering from the lack of basic services, infrastructure facilities and sub-standard housing in terms of quantity and quality.

\section{iv. The old part of the city:}

It is characterized by the small land divisions, which leads to deteriorated architectural and interior design with high density of buildings causing significant declination of privacy and ventilation. Houses design also showed that no consideration was given to the functions of the different vacant spaces within the house. The new buildings in such areas are high rise type over fifteen floors, which lead to ventilation problems and decrease in privacy. Generally, the old areas have traffic problems and deteriorated urban characteristics.

\section{v. The outskirts:}

On the outskirts, the design of buildings is characterized by the very small areas of spaces, it facts privacy below standards of ventilation and no sun penetration, and all the recommended conditions which should be available in a dwelling. Also vast areas of lands are being lost due to the inefficient desires.

\subsection{Results of studying the general master plan 2012}

S.O.W.A. analysis was implemented within studying Mansoura City master plan and the existing state of city after implementing it (Appendix 2). Conclusion of studying the results of the study was presented in summarizing in the following items.

a. Concept: It is based on the concept of Re-habilitation strategy, through replacement of the deteriorated residential areas, in addition to developing the existing areas.

b. Actions: All efforts must be made to maintain the city activities and to upgrade the city conditions separately

c. advantage: 
i. Stabilization of the current uses situation.

ii. Provision of more regional response in relocating the multi urban activities

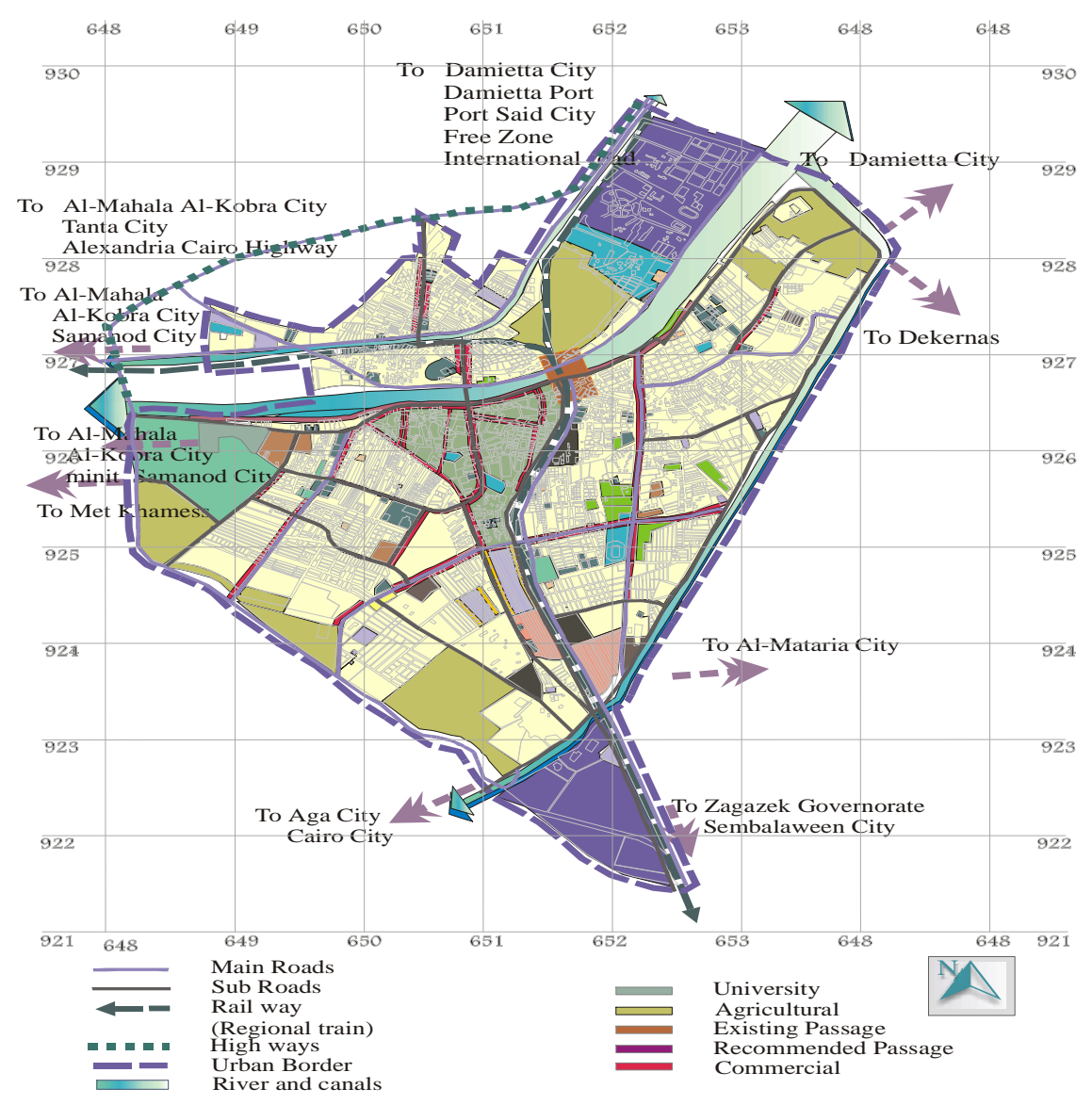

Fig 14, El-Mansoura City land use in 1994.

Source: Master Plan of El-Mansoura and Talkha cities, 2012, P.89

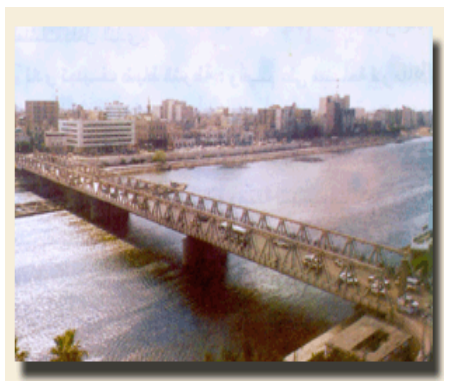

River Nile

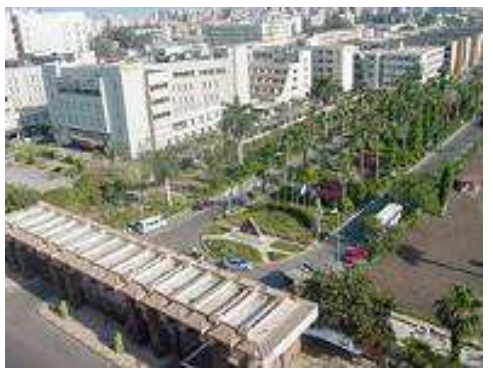

Mansoura University

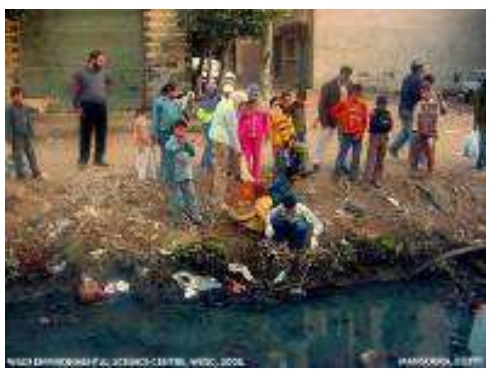

slum areas

Photo3: contradiction between two living standards in Mansoura City 


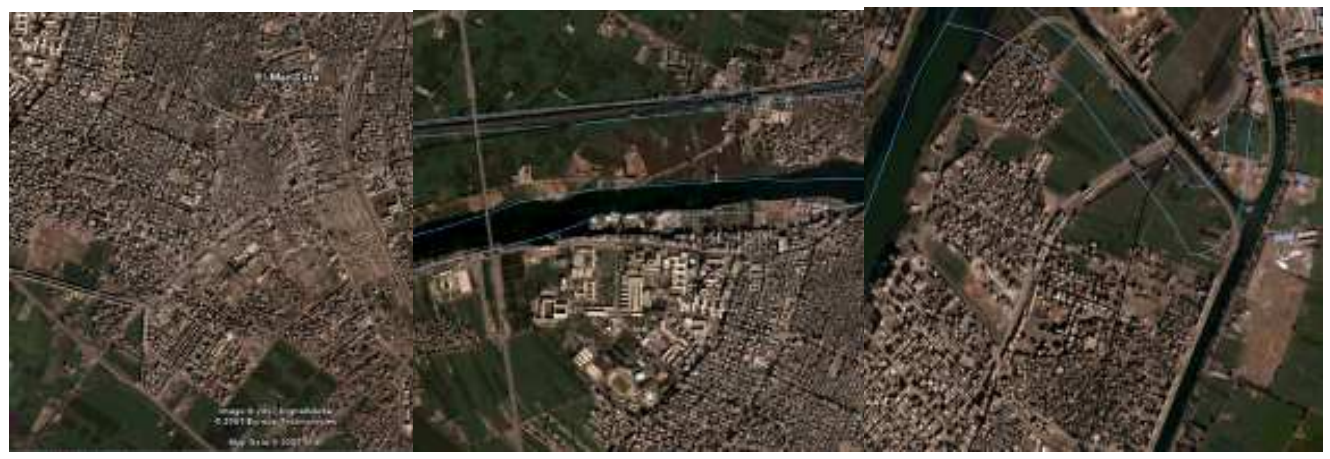

rural pockets in south part

rural pockets in west part

rural pockets in east part

Photo4: rural pockets inside of Mansoura City urban fabrics.

d. disadvantage: Defects of the general master plan 2012 were analyzed and concluded as follows:

i. But on the governmental level: the Dakahlia urban planning development strategy, had contradictions in implementing these strategies due to the lack of organization between the different departments.

ii. Also, it should be noted that the master plan 2012 roles and its goals ignored presenting the methodology to be applied, which might be used in managing the interaction between the city activities.

iii. The studies were based on old data (1986) and consequently led to wrong prediction for the future of the city urban planning.

iv. It ignored the external forces and the updating data information of the city.

v. Its goals did not solve the disadvantages of the master plan of 2000.

vi. It illustrated that $0.27 \%$ of the total laborers work in infrastructure field, but its services were not considered.

vii. The master plan ignored the adverse impacts that resulted from the noise, which is considered a severe pollutant.

viii. Planning problems may be increased, due to ignoring the implementation of most of the master plan 2012 recommendations.

ix. The general master plan presented the districts future extensions, but it did not include the urban criteria, which were based on.
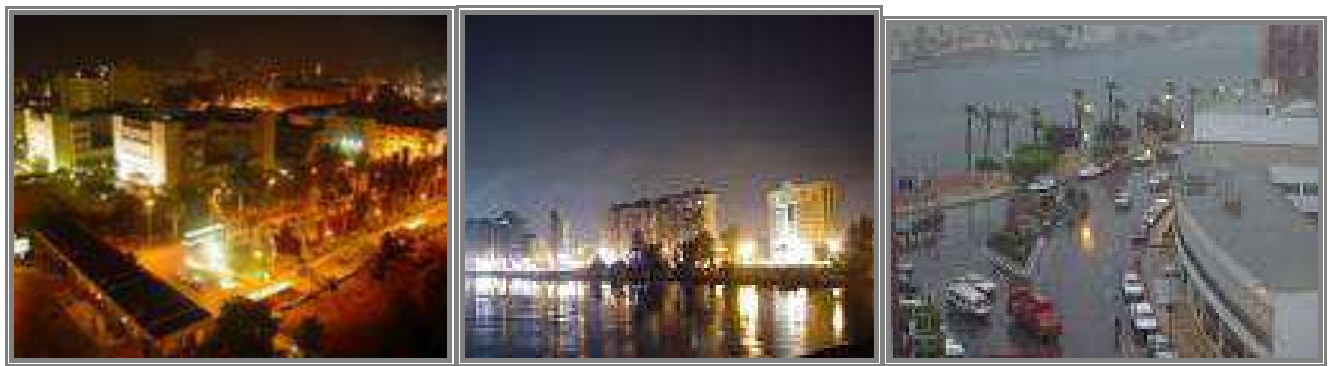

Photo5: Mansoura City Urban features

\section{Environmental impact assessment of El-Mansoura City (E.I.A.)}

Evaluating the impacts of El-Mansoura City urban problems due to the conflict 
between Delta Region, Dakahlia Governorate development policy and its applied strategies and the implementation of Mansoura City master plan 2012 is very important, so as to clarify the effective factors on that conflict. The Environmental Impact Assessment (E.I.A.) of El-Mansoura City will be measured using the "impact checklists" table, which is a method of combining a list of potential areas, which have to be taken into considerations when making the assessment. The different elements reveals the (E.I.A.) upon the whole city whether positively or negatively which is an indicator on how successful the general master plan 2012 was in developing the city and upgrading the housing conditions. The symbol $*$ represents the relation between the element and the type of effect, Table 4.

Table 4, summarizing of the Impact Checklist for (E.I.A.) of El-Mansoura City after implementing the master plan 2012.

\begin{tabular}{|c|c|c|c|}
\hline \multirow{2}{*}{ Element of assessment } & \multicolumn{3}{|c|}{ Impact } \\
\cline { 2 - 4 } & $\begin{array}{c}\text { Adverse } \\
\text { effect }\end{array}$ & No effect & Beneficial effect \\
\hline
\end{tabular}

\section{a.The general studies of the city:}

i. Geographical compatibility:

\begin{tabular}{||l|l|l|l||}
\hline Geographic location. & & $*$ & \\
\hline The city subdivision. & $*$ & & \\
\hline
\end{tabular}

\section{ii. Demographic compatibility:}

\begin{tabular}{|c|c|}
\hline 1. Population density. & * \\
\hline 2. Populations increase. & * \\
\hline 3. Population characteristics. & * \\
\hline
\end{tabular}

iii. Man activities and economical studies:

\begin{tabular}{|l|c|c|c|}
\hline \hline 1.Agriculture production. & $*$ & & \\
\hline 2.Zoological production. & $*$ & & \\
\hline 3.Tourism. & & & $*$ \\
\hline 4.Industrial activities. & $*$ & & \\
\hline 5.Commercial activities. & $*$ & & \\
\hline 6.Power of professional discipline labor. & & & $*$ \\
\hline 7.Investment of third "fifth strategy" plan. & & $*$ & \\
\hline
\end{tabular}

\section{iv. Infrastructure facilities:}

\begin{tabular}{|l|c|c|c||}
\hline 1-Potable water. & & & $*$ \\
\hline 2-Electricity and energy. & $*$ & & \\
\hline 3-Sewage. & $*$ & & \\
\hline 4-Waste disposals. & $*$ & & \\
\hline 5-Roads. & & & $*$ \\
\hline 6-Transportation. & & $*$ & \\
\hline 7-Traffic facilities. & $*$ & & \\
\hline 8-Communications grid. & $*$ & & \\
\hline
\end{tabular}


v. Basic services:

1-Primary education services.

2-High education services.

3-University education services.

4-The health and medical services.

5-Youth services.

6-Sport services.

7-Social services.

8-Culture centers services.

\section{vi. Environmental studies:}

\begin{tabular}{|ll|c|c|c|}
\hline 1. & Temperature. & & & $*$ \\
\hline 2. Wind. & & & $*$ \\
\hline 3. Rains. & & $*$ & \\
\hline 4. Humidity. & & $*$ & \\
\hline 5. Daylighting. & & & $*$ \\
\hline 6. Solar energy. & & $*$ \\
\hline
\end{tabular}

b. The urban planning studies of the city:

i. Urban planning:

1.Urban characteristics of El-Mansoura.
2.The urban pattern.

\section{ii. Land uses:}

1-Arrangement of the land uses types.

2-Urban spaces.

3-Recreational land use.

4-Agricultural land use.

5-Residential land use.

6-Commercial land use.

7-Industrial land use.

8-Leftovers.

9-Interaction between the various land uses.

\begin{tabular}{|c|c|c||}
\hline & & $*$ \\
\hline & & $*$ \\
\hline & & $*$ \\
\hline & $*$ & $*$ \\
\hline & $*$ & \\
\hline & $*$ & \\
\hline
\end{tabular}

iii. Residential studies:

\begin{tabular}{||l|c|l|l||}
\hline 1-The housing situation. & $*$ & & \\
\hline 2-The inhabited area. & $*$ & & \\
\hline 3-The construction methods. & $*$ & & \\
\hline 4-The building materials. & $*$ & & \\
\hline 5-The buildings heights. & $*$ & & \\
\hline 6-Developing the landscape around houses. & $*$ & & \\
\hline 7-Upgrading the urban pattern and land use. & $*$ & & \\
\hline
\end{tabular}


c. The urban expansion's characteristics:

i. Urban expansion:

\begin{tabular}{|l|c|l|l||}
\hline 1-Horizontal direction. & $*$ & & \\
\hline 2-The vertical direction. & $*$ & & \\
\hline 3- El-Mansoura City districts development. & $*$ & & \\
\hline 4-Developing the urban fabric. & $*$ & & \\
\hline
\end{tabular}

ii. Controlling of the land uses problems:

1-Developing the land uses.

2-Upgrading land uses activity integration.

3-Controlling the interaction between missland uses and urban encroachment.

\section{iii. Environmental problems that resulted from the urban expansion:}

\begin{tabular}{||l|c|l|l||}
\hline 1-Air quality. & $*$ & & \\
\hline 2-Water resources. & $*$ & & \\
\hline 3-Noise and vibration. & $*$ & & \\
\hline 4-Ground pollution. & $*$ & & \\
\hline 5-Electronic pollution. & $*$ & & \\
\hline 6-Aesthetic pollution. & $*$ & & \\
\hline 7-Cultural and behavior pollution. & $*$ & & \\
\hline
\end{tabular}

One of the major conflicts appears in this table. It should be noted that the adverse impacts appears to be exceeding the beneficial effects, tremendously, which consequently, reflects the failure of the master plan to achieve its goals in developing and upgrading the land uses and residential areas in the city. Matching to the above analysis, the degree of the environmental problems types were measured by ElGhonaimy on 2000, the Municipality of Environment and others, findings and conclusion of these measurements are summarized in, Table 5, as follows.

Table 5: example of the environmental problems types degree.

\begin{tabular}{|l|c|l|}
\hline \multicolumn{1}{|c|}{ Type } & degree & \multicolumn{1}{c|}{ Description } \\
\hline i.Air pollution & $\mathbf{0}$ & Destructive and killing pollution degree. \\
\hline ii.Water pollution & $*$ & Dangerous pollution degree. \\
\hline iii.Ground pollution & $\boldsymbol{\Delta}$ & Acceptable pollution degree. \\
\hline iv.Noise pollution & --- & No effect. \\
\hline v.Aesthetic pollution & $\mathbf{0}$ & \\
\hline \hline
\end{tabular}

- Acceptable pollution: it is under the pollution limit, characterized by no severe dangerous effects or health hazards, and could be controlled.

- Dangerous pollution: It is characterized by an over limit and has hazardous effects on the living, in the surrounding areas. This degree is found in ElMansoura City in many forms such as air pollution from Talkha fertilizers factory, the brick factories on the northern west of El-Mansoura, and Talkha's electricity power plant. 
- Destructive and killing pollution: It is characterized by the highly over pollution limit, which is not yet found in El-Mansoura City.

\section{THE S.W.O.T. OF EL-MANSOURA CITY}

Demonstrate the positive and negative sides, after examining the collected data (same elements of E.I.A. table), will be achieved through a table, which is point out the positive and negative aspects that already exists, and the development aspects that is expected to happen in the future. So, appropriate decision could be taken, so as to make the maximum use out of the positive opportunities available and avoiding the negative aspects which constitutes a threat to the city as a whole. Strengths Weaknesses Opportunities and Threats for the following elements were examined:

- Geographical city-state \& city subdivision

- Man activities and economical state.

- Basic services.

- Urban planning.

- Urban expansion of El-Mansoura City.
- Demographic situations

- Infrastructure facilities.

- Environmental factors

- Residential areas.

- Environmental problems.

Table 6: Factor: Results of the monitoring of El-Mansoura City urban planning

\begin{tabular}{|c|c|c|c|c|}
\hline & Strengths & Weaknesses & Opportunities & Threats \\
\hline 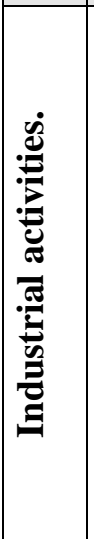 & $\begin{array}{l}\text { Its location in an } \\
\text { intermediate zone } \\
\text { between the } \\
\text { industrial capitals in } \\
\text { New Damietta and } \\
\text { Cairo, is considered } \\
\text { an asset. }\end{array}$ & $\begin{array}{l}\text { There were no } \\
\text { strategic plans to } \\
\text { manage its activities, } \\
\text { services and } \\
\text { infrastructure. } \\
\text { Urban problems and } \\
\text { environmental } \\
\text { pollution are the } \\
\text { results of the } \\
\text { existence of the } \\
\text { industrial activities } \\
\text { within the city and } \\
\text { the mixing of the } \\
\text { land uses. }\end{array}$ & $\begin{array}{l}\text { Due to the city's } \\
\text { location, the } \\
\text { industrial activities } \\
\text { offer work } \\
\text { opportunities and } \\
\text { commercial } \\
\text { activities. }\end{array}$ & $\begin{array}{l}\text { The uncontrolled } \\
\text { pollution that } \\
\text { resulted from the } \\
\text { industrial activities } \\
\text { beside the urban } \\
\text { problems is the } \\
\text { common threats to } \\
\text { the residences. }\end{array}$ \\
\hline ن & $\begin{array}{l}\text { It has a good } \\
\text { geographical } \\
\text { location between the } \\
\text { commercial centers } \\
\text { in Tanta, Mahala, } \\
\text { Damietta and Cairo. }\end{array}$ & $\begin{array}{l}\text { The mixed use of the } \\
\text { commercial } \\
\text { activities with other } \\
\text { activities leads to } \\
\text { heavy transportation } \\
\text { and traffic problems, } \\
\text { beside the generation } \\
\text { of noise. }\end{array}$ & $\begin{array}{l}\text { This good } \\
\text { geographical } \\
\text { location will } \\
\text { increase the } \\
\text { commercial } \\
\text { activities and hence } \\
\text { will change it's } \\
\text { economical } \\
\text { development in the } \\
\text { city. }\end{array}$ & $\begin{array}{l}\text { The commercial } \\
\text { activities will } \\
\text { increase the load of } \\
\text { the traffic on the } \\
\text { roads and the } \\
\text { bridges, causing } \\
\text { urban and } \\
\text { environmental } \\
\text { problems. }\end{array}$ \\
\hline
\end{tabular}

For example: samples from the Main activities and economical state (Industrial and Commercial activities) were selected and its Industrial activities and Commercial activities to present the sequence and process of the analysis (table6). Which are generally, it is a magnet and strong economic base. 


\section{CONCLUSION}

The absence of the cooperative between the Ministries of Development, New Communities, Housing and Utilities led to increase the Problems of Urban encroachment, which affect negatively the economic development process as mentioned in 2-2.

By, monitoring of the urban expansion and the changes of the land uses indicates that the general master plan of El-Mansoura City doesn't manage the urban expansion, nor control the sources of the environmental pollution. Not only the city has urban expansion problems but also it receives a reverse expansion from surrounding rural areas.

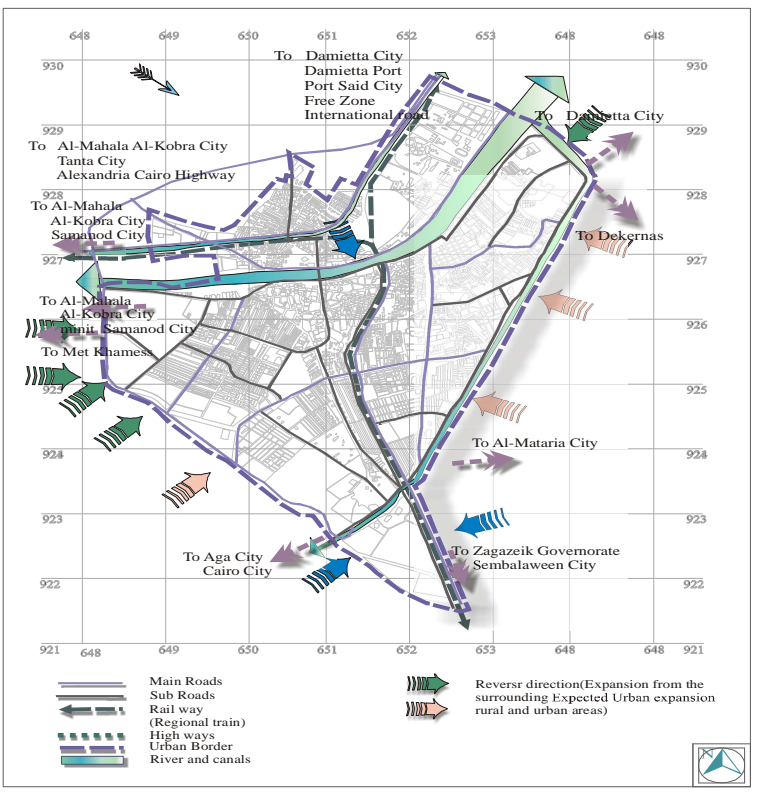

Figure 17. The reverse urban expansion from the surrounding area

That means the master plan performance was not fit to achieve its goals and objectives. Another thought should be given to the updating of the region urban policy after the failure of the master plan. Consequently, there is a need to represent a conceptual general master plan to solve the local urban planning problems in general, and improve the residential land use in particular.

This conceptual master plan strategy must be based on solving the city problems following a sustainable planning concept, trying to decrease the urban encroachments as possible achieving the improvement and upgrading of the urban planning of the city. Fig17 shows the normal and the reverse uncontrolled urban expansion from the surrounding area.

\section{RECOMMENDATION}

After studying and analyzing the general master plan 2012 for El-Mansoura City, and it's state of implementation, multiple urban and environmental problems emerged. This was due to the conflict of "Delta Region" Policy, "Dakahlia governorate" urban planning policy and its applied strategies upon ""El-Mansoura" City" urban developing causing some major point of weakness in the master plan 2012, and that led to the severe deterioration of the city in several aspects.

Referring to S.W.O.T table analysis which include the affecting elements in enhancing the urban and environmental conditions of the city or vice versa, the urban parameter, which affects the urban expansion, will be presented. It could be used to forecast the suggested solutions for the development of El-Mansoura City.

It is usually acknowledged that urban development strategies should be a part of a comprehensive plan. Yet, too often, even where a general master plan of "ElMansoura" City exists, it is hard to process and act in the city due to the following: 
i. The disorganized development actions.

ii. The lack of reality of the stated goals.

iii. The lack of coordination between planning and financing agencies

iv. The lack of trained personnel.

v. Goals are the most reasonable explanation, however, the failure of development plans is related to the inadequate assessment or monitoring of the problems to be tackled

vi. The resources which are available and the mechanisms that might maximize the effectiveness of those resources

The fundamental principals of solving El-Mansoura City urban problems, which are found from the detailed study of El-Mansoura City (urban encroachment, misuses of land, environmental pollution, and housing conditions problems) must be started from the general level policy and be directed towards the governmental level strategy and ended by the local level as follows (fig18):

\subsection{Regional level: The}

\section{Delta region planning policy:}

Dealing with the problem on the regional level aims at controlling the external sources and preventing the causes of the problems on the Delta region level. This could happen through the managing of the Delta regional planning policy to modify it towards the sustainable urban planning concept and to assess the largest urban economic magnets in serving the residences of the Delta.

\subsection{Governmental level: Dakahlia urban planning development strategy:}

The scope of the governmental level occurs through modifying Dakahlia urban planning development strategy to control the main land problems in Dakahlia governorate, which resulted from the land degradation. It may proceed through controlling the man made factors, which are related to the urban extensions on the arable land and the land pollution, in addition to control the emigration of the laborers to the governorate.

\subsection{Local level: The planning of El-Mansoura City:}

The scope of improving the planning of El-Mansoura City is through solving the problem on the local level. The main goals to be tackled are:

i. Developing the master plan of El-Mansoura City.

ii. Controlling the urban expansion of El-Mansoura City.

iii. Controlling the sources of the environmental problems in El-Mansoura city. 
Figure 19 illustrates the proposed governmental action process towards solving land problems in urban level starting from Regional level pass by governorate level ended by City level, which was designed by the researcher to organize actions flow in manageable method.

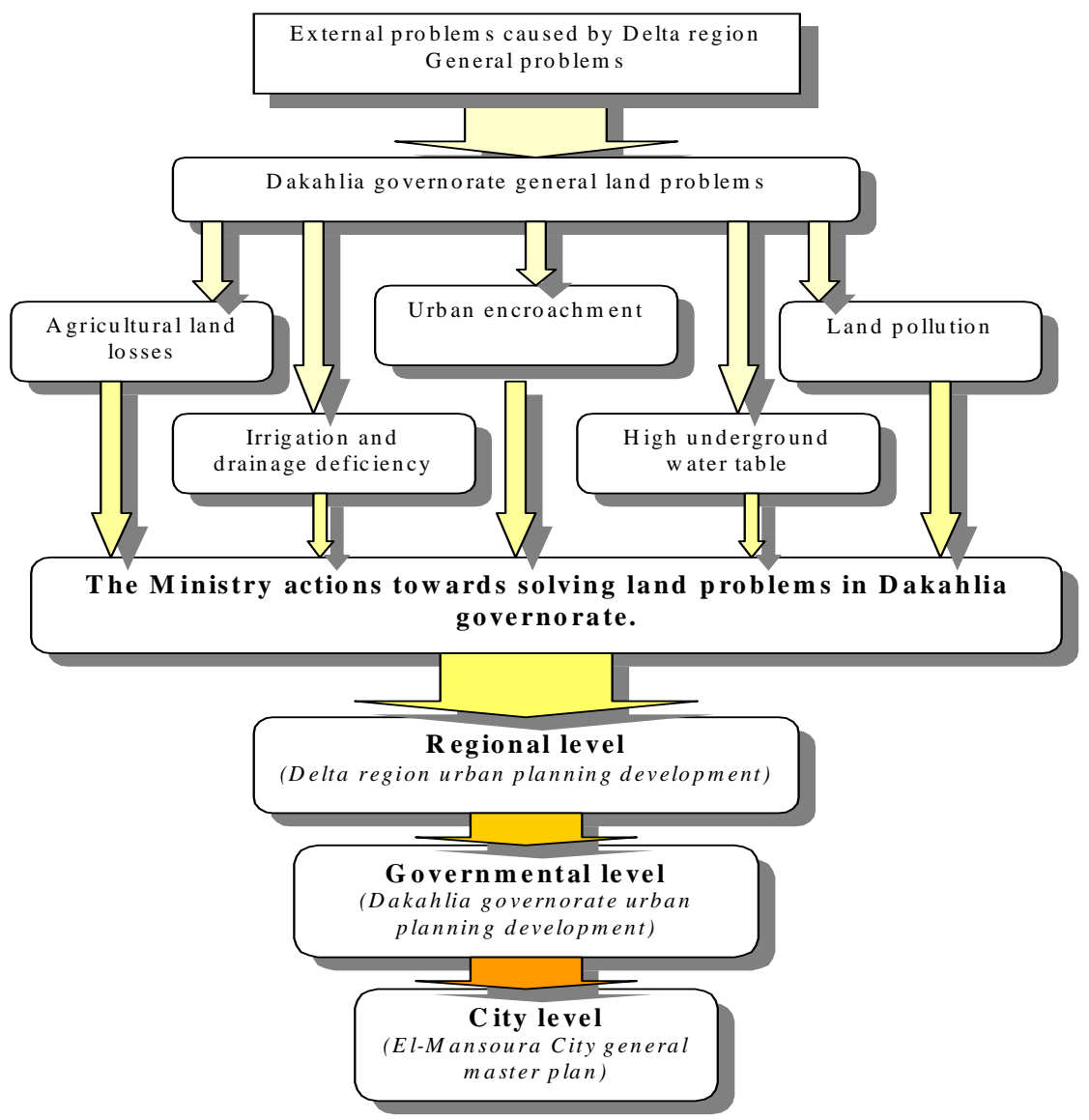

Fig. 19: The governmental action process levels towards solving land problems in Dakahlia governorate.

\section{REFERENCES}

1- Ahmed O. El-Kholei, Transformations in Popular Attitude, Customs and Beliefs: A Framework for the Development of Poor Rural Settlements in Egypt, Prepared for Conference on Rural-Urban Linkages Organized by The General Organization for Physical Planning Cairo, Egypt, 13-16 December 2005

2- El-Dardiry, D. H., Environmental housing conditions in new urban settlements in Egypt, Ms.c. thesis submitted to institute of graduate studies and research, University of Alexandria, 1997, P51.

3- El-Ghonaimy, E. H, Environmental Assessment of Urban Area, Monitoring the Changes of Urban Expansion and Land Use Pattern and its Impacts on Residential Area, $\mathrm{PhD}$. thesis submitted to Faculty of Engi., Mansoura Uni, 2000

4- Internet http://ideas.repec.org/p/dia/wpaper/dt200408.html

5- Housing international conference, Policies \& housing systems for low income 
communities, Governments role in self-help housing in urban developing areas: the site and services approach., Ministry of development, New communities, housing and public utilities., Cairo, 1992, P. 55

6- Ministry of Housing, Infrastructure and New Communities, Urban planning center for Delta region, the regional planning for Dakahlia governorate by 2017, General report, P. 7.

7- Abdel Fattah Nassef et all, Egypt human development report, UNDPE\& INP, Cairo 1996, P.P 135-136.

8- General Master Plan of El-Mansoura and Talkha Cities, year 2012, P.P. 5-20.

9- Topography map in atlas of Egypt. Scale 1: 100.000.

10- Dakahlia governorate, supporting and decision-making center, 1998, P.2

11- General authority of information, Annual report, 1998, no-number.

12- G.O.P.P, Comprehensive development strategy for Delta region, working Paper No.(2), Cairo, 1992.

13- Dakahlia governorate, Agriculture sector, unpublished yearly report, the secretary office, 1998.

14- El-Eshmawy, K.H., Impact of tile drainage on crop production in Dakahlia governorate, M. Sc., Faculty of Agricultural, Mansoura University, Egypt, 1992.

15- Serag El-Din, H.M., "Geology Hydrological and Hydrological studies on Quaternary Nile Delta Aquifer", Ph. D. Thesis, Faculty, of Science., Mansoura University, Egypt1989, unknown page.

16- Mesheraf and Fesal, 1995, P.40.

17- W. A. Abd-El-All, "El-Mansoura City field studies", M. Sc. thesis, submitted Cairo University, Faculty of Arts, 1971.

18- Master Plan of El-Mansoura and Talkha Cities, 1994 P. P. 5 -10.

19- Dakahlia governorate periodical magazine, 1996, P.37

20- W. H. Habeeb. part one, 1991, P.354.

21- M. A. Hasouna, P.1

22- E., E., Badran, Overcrowding problems in Egypt., MSc., Architectural Department, Faculty of Engineering, Alexandria University, 1985, P.2

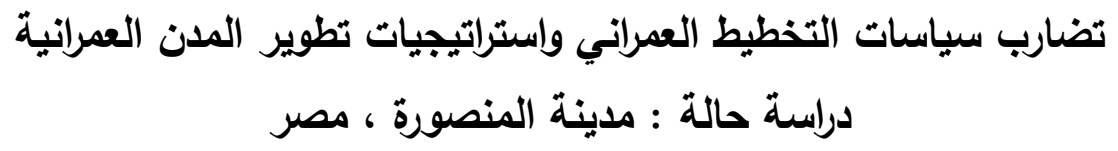

يناول هذا البحث مناقتشة مشكلة النمو العمراني للمدن العاصمية والتي تحدث غالبا بصفة مضطردة على التى حساب الأراضي ، خصوصا وإن اهتمام المخططين بالتتمية العمرانية يأتي في إطار تحقيق احتياجات

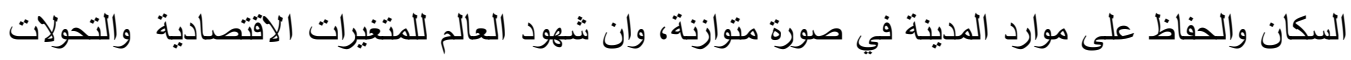

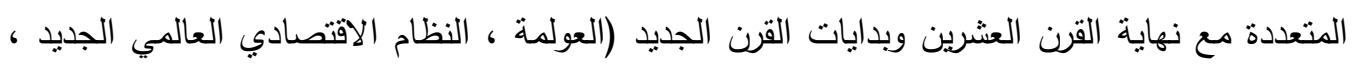

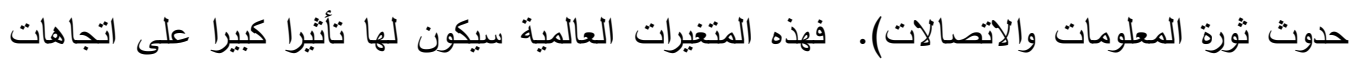
التتمية العمرانية في مصر وخاصة في تحديد اتجاه ومعدل التتمية العمرانية. 
وترجع أسباب اختيار مدينة المنصورة كحالة دراسية لما لموقعها من مواصفات تتشابه مع المدن الإقليمية والتي يتم النمو الحضري بها على حساب الأراضي الزراعية المحيطة، وهو النمو غير البسيط خاصة

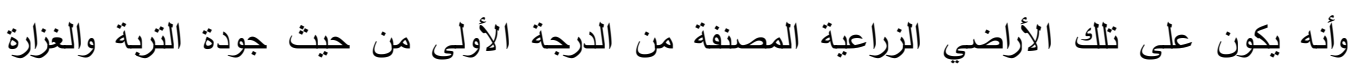

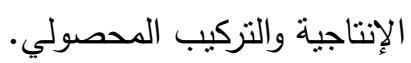

ومن ثم ظهرت أهمية دراسة ورصد نمو المدينة لتلافى الآثار السلبية الناتجة عن النمو غير

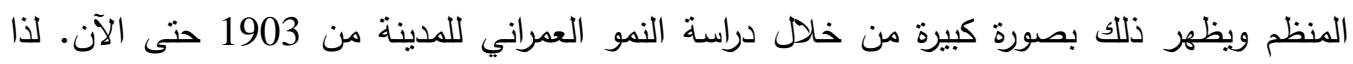

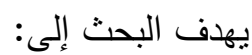
• تقييم مدى جدوى الإجراءات الحكومية تجاه مشاكل النمو الحضري ومدى نجاح المخطط الثشامل لمدينة المنصورة لسنة 2012 في حل مشكلة العمران وتطوير المناطق السكنية المندهورة.

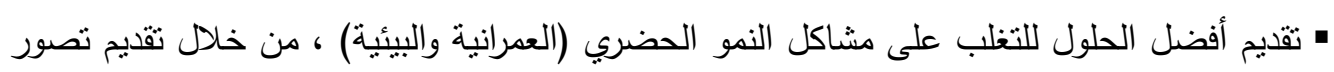
جديد للمفهوم المتبع لطابع المخطط الثامل لمدينة المنصورة بفرض تحسين ظروف ونوعية الإسكان، وذلك من خلال نظرة شاملة مستقبلية مبنية على التواصل والاستدامة ، والاستغلال الأمثل للموارد

المتوفرة بالمدينة.

• تحليل وتقييم السياسات والاستراتيجيات المقترحة لحل مشاكل النمو العمراني في مخططات التتمية لتقديم تصور جديد لمخطط مدينة المنصورة العام.

واختص مجال البحث بدراسة النتائج السلبية لنمو مدينة المنصورة الغير مخطط على استعمالات

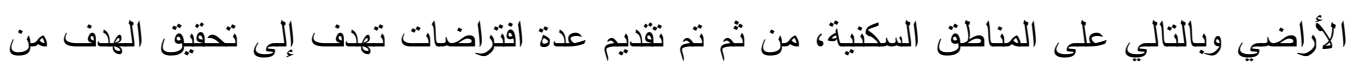
البحث كالتالي:

• على مستوى إقليم الدلنا: أن سياسة التتمية العمرانية بالإقليم يجب أن تتشىى مع القدرة الاستيعابية

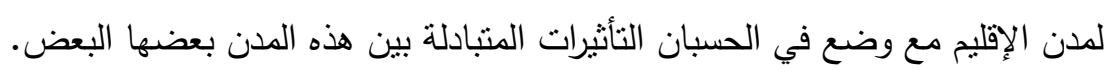

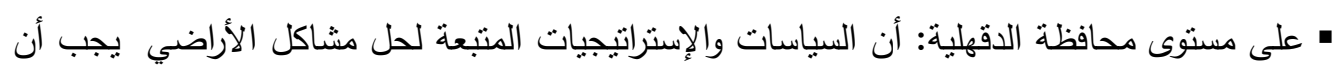

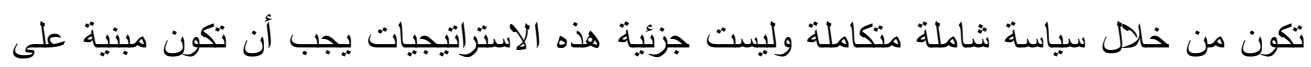
فكر التتمية المستدامة. • على مستوى مدينة المنصورة: أن المخطط الثامل لمدينة المنصورة لعام 2012 ليس مناسب لحل

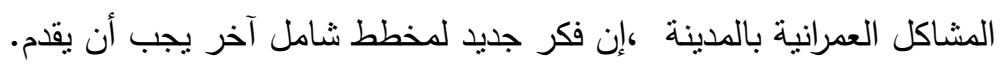

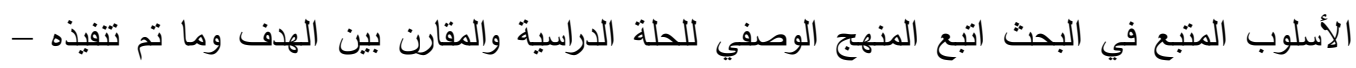

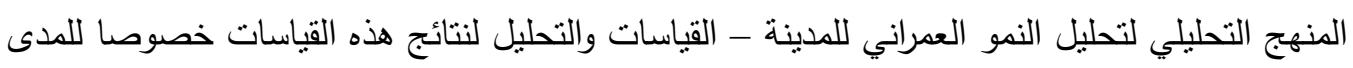
التلوث الحادث بالمدينة. 